Тијана Балек

Универзитет у Новом Саду

Филолозофски факултет

Одсек за славистику

tijana.balek@ff.uns.ac.rs
УДК 811.161.1'36

https://doi.org/10.18485/slavistika.2021.25.2.6

Оригиналан научни рад

примљено 27.4.2021.

прихваћено за штампу 6.10.2021.

\title{
О ЛЕКСИЧКОЈ КАРИТИВНОСТИ РЕПРЕЗЕНТОВАНОЈ ГЛАГОЛИМА И ГРАМАТИКАЛИЗАЦИЈИ ПАРТИЦИПАНАТА У РУСКОМ ЈЕЗИКУ
}

У раду је описана једна од могућности представљања каритивног значења лексички самосталним јединицама - глаголима. Пажња је усмерена на глаголе из домена отуђивања будући да аутор сматра да они каритивност показују у својој дубинској структури јер, уколико је нешто отуђено, друга страна је лишена датог ентитета. Показано је, такође, да се у својству каритива могу користити и глаголи из семантички супротне скупине глагола присвајања те придеви без посматране компоненте, уколико се као важни аналитички фактори узму перспективизација и информациона структура (каритивне) ситуације.

Кључне речи: каритивност, глаголи, апсенс, оријентир, партиципанти, агенс, субјекат, отуђивање.

The paper describes one possibility of representing caritive semantics with verbs as lexically independent units. Attention is focused on the verbs from the domain of deprivation since we believe that they possess caritive semantics in their inner structure. We also show that the verbs from the semantically opposite group can have caritive properties as well as adjectives without an observable meaning if we take perspectivization and informational structure of the (caritive) situation as important analytical factors.

Keywords: caritives, verbs, absentee, point of orientation, participants, agent, subject, deprivation.

1. Категорија каритивности ${ }^{1}$ (лишености; од лат. caritas - 'недостатак', 'оскудност' према Толстая (2008)) подразумева одсуство или неукљученост једног елемента ситуације, тзв. апсенса, а граматички се експлицира на различите начине: на синтагматском плану помоћу предлога без с именичком допуном у генитиву (Вышел без куртки/Изашао је без јакне), на творбеном префиксом без- (безответный вопрос (питање без одговора), бездетная женщина (жена без деце)) и др. (Боханова 2013: 169-173, Оскольская и др. 2020: 7-25). Каритивно значење се може изразити и лексички самосталним јединицама - нпр. глаголима, које посматрамо у датом раду. Наиме, апсенс, елемент који недостаје у каритивној ситуацији и њен је обавезни члан, може бити семантички субјекат/објекат, односно имати адвербијалну или атрибутивну функцију, што значи да је обавезно лексички изражен. Ипак, ситуација често подразумева неукљученост бар још једног (другостепеног) учесника који му је супротстављен - тзв. оријентир (Оскольская и др. 2020: 16-17). Појмове апсенс и оријентир не треба схватити као семантичке улоге у уобичајеном

1 Насупрот посесивности, није на одговарајући начин заступљена у лингвистичким истраживањима (према Иванов 1995: 5), посебно у словенским језицима. 
смислу; они су у релацији један према другом (Оскольская и др. 2020: 17). У каритивној ситуацији поменути партиципанти ${ }^{2}$ не морају бити коагенси (као када је реч о комитативној ситуацији) $)^{3}$, већ може постојати агенс који управља њоме, при чему је оријентир пасивни посесор. Другим речима, позиција коју ће заузети партиципанти у одговарајућој синтаксичкој целини зависи најпре од рекцијских карактеристика глагола-предиката, али и од значења представљеног датом целином те средстава којима се то постиже.

Анализа је усмерена на оне глаголе у руском језику којима се изражава одсуство једног ситуативног елемента(или више), идентификацију семантичких типова и, посебно, на моделе граматикализације апсенса, оријентира и др. партиципаната (каритивне) ситуације који се подразумевано јављају уз посматране глаголе. Осим тога, настојимо да покажемо да је могућа интерпретација каритивности и када у контексту није присутно ниједно од горепоменутих средстава којима се она обично означава. Пошто у русистичкој литератури нема радо$\mathrm{Ba}^{4}$ у којима се глаголи посматрају као каритивни показатељи, мислимо да има смисла проширити листу партиципаната у складу с рекцијским особинама глагола иако је на реченичном нивоу оријентир некада нерелевантан чинилац - у случајевима типа Иван открыл бутылку без штопора (када инструмент није био укључен у ситуацију отварања - оријентир је Иван) или безличним реченицама Холодно без солнцза (Оскольская и др. 2020: 17).

2. Мноштво је глагола којима се отуђивање/лишавање може изразити (в. ТСРГ 1999: 573-575), као брать - взять, красть - украсть, овладевать - овладеть, разоружать - разоружить, отнимать - отнять и др., али прототипским каритивима сматрамо лишать (ся) - лишить (ся), отчуждать(ся) - отчудить ${ }^{1}(с я)$ и отсутствовать. Овога пута, уз наведене, размотрићемо и отобрать - отбирать, отнимать - отнять, удалять (ся) - удалить (ся), терять (ся) - потерять (ся)/утерять (ся), утрачивать (ся) - утратить (ся) и не хватать - не хватить. Међутим, услед повезаности тематских потпоља отуђивања (у чијој је суштини каритивно значење) ${ }^{5}$ и присвајања/стицаға, пошто отуђивање/лишавање (имајући у виду перспективизацију ситуације), заправо, представља стицање са негативном оценом (према Balek 2018: 342), глаголи получать и получить анализираће се у каритивном контексту. С обзиром на вишезначност грађе, фокусирамо се на семантичке сегменте у којима се остварује каритивност.

2 То су учесници повезани не само са ситуацијом него и међусобно, те у различитим односима имају различите улоге - нпр. агенс и пащијенс (најукљученији у ситуацију), односно комитатив, бенефицијент или инструмент (најмање укључени) (Lehmann 1991, 2006). У раду агенсом сматрамо партиципанта укљученог у ситуацију (с могућношћу њене контроле) не вршећи типологизацију.

${ }^{3} \mathrm{O}$ комитативним конструкцијама и контроли ситуације в. детаљно код Архипов (2009).

${ }^{4}$ С. Осколска и др. помињу отсуствовать, лишать(ся) и не хватать као лексичка средства којима се каритивно значење презентује, али анализа није дата (Оскольская и др. 2020: 21).

${ }^{5}$ У раду изједначавамо појмове каритивност, лишеност, непоседовање и одсуство иако их одређени аутори диференцирају (в. Радчук 2019), премда не узимају глаголе као предмет анализе. 
2.1. Каритивни фокус ${ }^{6}$ денотиран глаголима лишать и лишить је на одсуству nосесије. ${ }^{7}$ Наиме, због својих рекцијских особина, наведене лексеме захтевају да апсенс (представљен конкретним/апстрактним именицама, живо /+, -/) буде граматикализован генитивом. Дати глаголи (лишать са ширим семантичким опсегом) у односу су видске корелативности када је реч о поништењу каузиране посесивности, али не и када се ради о некаузираној. Лексички се наведена појава манифестује помоћу (кратких или дугих облика) трпног глаголског придева лишенный (-ая, -ое, -ble). У примерима (3) и (4), где је експлициран како апсенс (на позицији објекта - элементарной логики и стабильности) тако и оријентир (субјекат, који утиче да дође до лишавања - субъективизм, обла$\kappa a)$, наведени глаголи представљају видске парњаке. Уз то, глаголом лишать означавају се временски неспецификоване активности: (1) Это лишит крупных операторов возможности инвестировать в современные технологии 8 ...; (2) И люди заплюют того, кто лишит постаревиую собаку заслуженной чести; (3) Субъективизм, излишняя ангажированность таких крайних суждений лишает их элементарной логики; (4) Облака, идущуие нескончаемой вереницей по диагонали вверх, лишают его стабильности. С друге стране, у пасивним конструкцијама без каузаторског елемента може да се јави једино глагол лишить у облику трпног глаголског придева лишенный (са резултативним значењем), а замена с глаголом (или пак конструкцијом) супротног граматичког садржаја није могућа због условног значења које пасивни каритивни облик с атрибутивном функцијом поседује у укупној семантичкој структури, што се, по правилу, реализује пре радње ситуације денотиране читавом реченицом, уп.: (5) Сегодня можно говорить только об обществе, лишенном смысла; (6) Чередование времен года как явление не лишено печали.

2.1.1. Код рефлексивних облика каузаторско деловање субјекта је маркирано постфиксом -ся, премда је оно (у активним конструкцијама) и лексички означено, нпр. заменицом ты или именицом боги: (6) А если у тебя работа за границеей? Тогда ты лишаешься источника доходов; (7) А если боги лишаются права влиять на этот мир, то разрушается понятие «бог».

2.2. Отчуждать (ся) и отчудить ${ }^{1}(c я)$ каритивни фокус усмеравају на (метафоричко) кретање којим се апсенс удаљава од оријентира, неког његовог дела или пак својства, а дата транспозиција обухвата и емоционални или психички домен. Код нерефлексивних облика отчуждать и отчудить ${ }^{1}$ апсенс се граматикализује на два начина:

2.2.1. Акузативом без предлога, када је представљен апстрактним реалијама које су у односу део - иелина с надређеним појмом/особином; уп. наредни пример, у којем се остварује и метафоричко аблативно кретање (карактеристично за отчуждать): (8) Когито-онтологийные ножницы разрезают и отчуждают

${ }^{6}$ Под каритивним фокусом подразумевамо тип ситуативног одсуства који се манифестује. Најчешће се ради о посесији (материјалних/апстрактних ентитета), али у обзир може доћи кретање, као и са̂мо присуство и сл.

${ }^{7}$ Без референције на то да ли је до резултата активности дошло насилним путем или не.

${ }^{8}$ Примери су преузети из електронског корпуса руског језика (даље НКРЯ) чија се приступна адреса наводи на крају рада. 
«индивидуальность не только людей, но и вещчей», всю духовную жизненность человеческого мира, отчуждает любую интимность, веру... Помоћу датог модела граматикализације апсенса изражава се и одсуство посесије насилним путем: (9) а) Все они принудительно отчуждают земли прежних крупных владельиеев... / б) Отчудить участок у народа-латифундиста для того, чтобь дать очаг народу-скитальиу, есть акт справедливости.

2.2.1.2. Акузативом у конструкцији где је оријентир представљен генитивом са предлогом от. Уколико се у контексту реализују и апсенс и оријентир, аблативна компонента удаљавања подразумева да је оријентир (замишљена) тачка на којој метафоричко кретање почиње (секундарна допуна), док је апсенс позициониран непосредно иза или испред глагола и представља његову примарну лексичку допуну. Одсуство се не реализује на иницијативу оријентира нити он на било који начин на њега утиче: (10) [...] и это отчуждает артиста от слушателя, придает исполнению характер позы; (11) [...] совершенная разность в первоначальных впечатлениях отчуждает их друг от друга. У наведеним примерима каузатори каритивних ситуација јесу појмови лексикализовани показном заменицом это (пример 10) односно вишечланом синтагмом совершенная разность в первоначальных впечатлениях (пример 11), па и апсенс и оријентир представљају семантичке објекте.

2.2.2. Рефлексивне форме отчуждаться и отчудиться, према МАС, имају искључиво емоционално значење, у којем се и манифестује каритивност. За разлику од нерефлексивних, постфиксални облици се углавном употребљавају с предлогом om којим се, у оквиру генитивне конструкције, граматикализује оријентир, док је апсенс у номинативу (на позицији семантичког субјекта и иницијатор каритивне ситуације), уп.: (12) Сам чувствую, как [я] отчуждаюсь от средь, от друзей; (13) Горько было мне читать ваши слова о том, что я отчудился от вас и Жени, дорогая моя; (14) Со смерти своей жены в 1915 году он отчудился от жизни...

2.3. Глагол отсутствовать нема видски кореспондент свршеног вида, па денотирана ситуација нема предодређен завршетак, а одсуство/неукљученост, који обухватају како просторну (пример 15) и временску димензију (16) тако и посесију (17), трајни су квалификатори активности. Апсенс је представљен различитим ентитетима граматикализованим номинативом на субјекатској позицији. Уп.: (15) В стране отсутствуют случаи смерти от кори; (16) Сколько времени она отсутствовала, я не знаю; (17) [...] перевод нельзя ни отправить, ни получить в местности, где отсутствует хорошо развитая инфраструктура...

2.4. У примарном значењу насилног отуђивања каритивну компоненту манифестују и отобрать $(c я)$ - отбирать $(c я)^{9}$, са специфичном граматичком

\footnotetext{
${ }^{9}$ Премда је у БАС наведено да отобраться и отбираться функционишу у свом секундарном значењу као пасивни облици и у каритивном домену (уп.: Вдова платить подати не могла, и земля от семьи немедленно отбиралась - БАС 1959/8: 1241), на основу грађе из НКРЯ запажа се да се у савременом руском језику они користе у значењу 'одабрати, изабрати', 'састати се', ‘проћи даље, у наредни круг такмичења'. Последње је примећено само код варијанте НСВ.
} 
реализацијом апсенса и оријентира. Наиме, иако често долази до изједначавања улога агенса и оријентира, оно ипак није обавезно; уп. следећи пример, где агенс (лексикализован заменицом я у номинативу) није оријентир: (18) Представьте, что я отбираю у кого-то сапожную мастерскую со словами: «Мой вице-президент будет ею заниматься!» Наиме, оријентиром сматрамо (пасивног, непознатог) посесора (уп. конструкцију с предлогом $y-y$ кого-то) отуђивог ентитета - апсенса, семантичког објекта, граматикализованог синтагмом у акузативу (сапожную мастерскую). Истоветан модел функционише и с отобрать уколико долази до контекстуалне диференцијације наведених трију елемената ситуације: у (19) агенс је Ярославль, оријентир-посесор Иваново, док је апсенс вишечлана синтагма с објекатском функцијом звание города невест: (19) [...] после последней переписи населения Ярославль отобрал у Иваново звание города невест и стал самым «женским» городом России. С друге стране, у (20) агенс јесте и оријентир (означен заменицама кто и $m е x)$, који врши отуђивање апстрактног апсенса, лексикализованог придевом у објекатској функцији последнее. Уп.: (20) В племени уважали не тех, кто помыкает другими, отбирает у них последнее, а тех, кто, наоборот, делится добытым.

2.5. Недозвољено присвајање карактеристично је и за отнимать - отнять ${ }^{10}$, уз условно диференцирање, у зависности од контекстуалних елемената, две готово истоветне каритивне компоненте - неукључености и лишености. Наиме, у значењу 'померити у страну, склонити' долази до изражаја неукљученост, ${ }^{11}$ док је у осталим реч о лишености. Са аспекта хијерархизације елемената унутар каритивне конструкције (на овакав начин посматрана) лишеност има виши статус јер се њоме активно модификује ситуација. УП. у (21), где је агенс (који управља активношћу отуђивања) особа, припадник какве групације (больщевики), оријентир (пасивни посесор) је означен именицом те граматикализован генитивном конструкцијом с предлогом $y(y$ семьи), док је апсенс на позицији семантичког објекта граматички формализован акузативном синтагмом всё остальное: (21) А потом пришли больщевики и отняли у семьи всё остальное. С друге стране, агенс може бити и апстрактан појам (христианство), као и апсенс који је, како видимо, представљен и генитивном синтагмом (радости жсиз$н u)$, док је оријентир-посесор људско биће (у человека): (22) Иногда создают превратную картину, что христианство отнимает радости жизни у человека. Могуће је да агенс и оријентир буду презентовани истоветним ентитетом те да је реч о неживој реалији, као и да апсенс буде апстрактан појам, уп.: (23) Нечаянно прочитанные слова словно отняли силу; (24) И тут - плевок, плевок, который отнимает последнюю надежду... Апсенс, међутим, може бити и неки део тела граматикализован акузативом када се, према МАC, има у виду да је он отклоњен оперативним путем: (25) Китаеи, придя в себя, горько заплакал и стал жаловаться, зачем у него отняли ногу.

${ }^{10}$ У примарном значењу глагола отнять диференцирају се компоненте 'узети (нешто) од некога упркос његовој жељи', 'овладати чиме; присвојити себи' и 'лишити (кога) нечега' (в. MAC).

${ }^{11}$ УП. Шурочка уже успела справиться с собой и отняла платок от лица (МАС): апсенс платок бива искључен из даљег тока ситуације, али се може поново укључити у њену реализацију. 
2.5.1. Код рефлексивних варијаната отниматься и отняться апсенс често означава део тела, ${ }^{12}$ најчешће језик, екстремитете и сл., који је одузет. У датом случају каритивност је метафоричка будући да је апсенс формално присутан, али са (трајно или привремено) модификованом функцијом. Осим тога, како показују примери (26) и (27), апсенс је на позицији семантичког субјекта, дакле, граматикализован је номинативом. Уп. нпр.: (26) Шевельнуться не могу. Руки, ноги отнялись; (27) Тотчас же отнялись у него рука, нога и язык.

2.6. Удаљавање посредством (метафоричког) кретања запажа се и у делу семантике глагола удалять (ся) - удалить (ся). Наиме, у погледу денотирања каритивности узета су у обзир значења с каузаторским елементом - 'одстранити (на какав специфичан начин)', 'одстранити оперативним путем', 'ослободити се нечега' којима се означава апсолутни престанак укључености апсенса у ситуацији; прецизније, реч је о његовом непостојању. ${ }^{13}$ Уп.: (28) Eмy благополучно удалили меланому, он на днях выписывается; (29) А этому удалим опухоль под местным наркозом.

Са временског аспекта каритивност може бити и привремена, често кад је реч о буквалном кретању апсенса (живо /+/) које је проузроковао агенс: (30) Прут удалил из кухни посторонних и, растравляя в себе воинственный дух, пошел на пристуn. Уколико се пак има у виду емоционално или друго апстрактно удаљавање, чешће се уз посматрани глагол користи предлог от. Оријентир је у датом случају позициониран лево од наведеног предлога. Уп.: (31) Конечно, после смерти Сталина в советском обществе произошли существенные изменения, которые удалили его от идеального типа тоталитаризма. Међутим, у значењу 'лишити кога могућности да учествује у нечему; да се бави чиме' оријентиром се лексикализује врста активности која је апсенсу недоступна, док апсенс представља особу којој је онемогућено да се бави одговарајућим послом. Каузатор те немогућности (лишености) је агенс, али је он у следећем примеру непознат: (32) Во-вторых, полициймейстера удалили от должности, а прочих недовольных разослали в заточение по уездным городам.

2.7. Опште одсуство односно поништење посесије денотирано глаголима утрачивать и утратить спецификује се помоћу глаголских објекатских допуна у акузативу (ређе генитиву) којима се граматикализује апсенс. Уп. апсенсе интерес, инстинкты и достижения те оријентире-агенсе она и собаки у примерима који следе: (33) Она сама не желала больше заниматься английским и утратила интерес к детективным романам; (34) Собаки утратили некоторые инстинкты, свойственные диким зверям. Слично се понашају рефлексивне варијанте, а апсенс је (због присутног маркера рефлексивности) на позицији субјекта. Уп.: (35) Их плодотворная связь не утрачивается и в дальнейшем; (36) Эти вопросы множатся с каждым годом, иллюзии утрачиваются одна за другой.

${ }^{12}$ Срећу се и апстрактне именице, а могућа је реализација пасивног посесора помоћу конструкције $y+$ ген.: Под его знаменем отнимались силы у пишущих людей, он был средством давления на писателей и читателей.

${ }^{13}$ Апсенс је реметилац нормалног тока активности чијим се отклањањем она несметано обавља. 
2.8. Глагол терять $(c я)$ специфичан је у погледу граматичке информације која се тиче образовања видских кореспондената и њиховог међуодноса. Наиме, у већини својих значења терять (видски кореспондент је потерять) функционише као каритивни показатељ чија се семантичка својства спецификују глаголским (објекатским) допунама - апсенсима (конкретним или апстрактним; уп. ниже время и цуелостности), док су оријентири представљени као субјекти (мама, его герои): (37) Между тем мама теряет время, а кожная инфекиия разрастается; (38) При всей детальности анализа его герои не теряют изелостности, остаются живыми. Уп. трансформисане горенаведене примере: (37a) Между тем мама потеряла время, а кожная инфекция разрасталась; (38а) При всей детальности анализа его герои не потеряли ичелостности, остались живыли.

2.8.1. Међутим, у примарном значењу ('лишити се чега услед непажње') терять шири своју видску парадигму, ${ }^{14}$ те му у својству видског кореспондента одговара и глагол утерять, а апсенси су, најчешће, апстрактне именице у акузативу којима се денотира какво својство/особина, уп.: (39) Он утерял [потерял; терял] контроль над своими чудачествами; (40) [...] Александр Федорович давно утерял [потерял; терял] болтливость, но гимназистом в душе остался. Из лексикографског описа глагола утерять примећује се да он има опште значење лишености, те се чини да би могао одговарати мотивном у свим његовим значењима. Ипак, анализа грађе из НКРЯ показала је да постоје извесна одступања у односу на речничке наводе: уз глагол утерять се изузетно ретко ${ }^{15}$ као апсенси јављају лексеме с обележјима живо /+/, а именица работа као (објекатска) допуна наведеном глаголу није идентификована ни у једном примеру, док се у својству апсенса уз потерять среће у немалом броју случајева. Уз то, и са̂м глагол утерять поседује специфичност видске парадигме, с обзиром на то да лексикографски подаци говоре да је његов општи парњак НСВ мотивни терять, док у примарном ${ }^{16}$ поседује (и) секундарно имперфективизовану варијанту утеривать (лични глаголски облици у НКРЯ срећу се у свега 6 примера). Формира се, дакле, трочлани низ (триплет) терять - утерять - утеpuвать $^{17}$, у којем сваки репрезент показује сопствене специфичности.

2.8.2. У примарном значењу глаголу теряться, према МАС, видски кореспонденти су како потеряться тако и утеряться. Међутим, сагледавши семантичке карактеристике апсенса̂, уочили смо да утеряться кореспондира са мотивним не само у примарном већ у највећем броју значења у семантичкој структури. Дакле, када је реч о пасивном неукључењу у ситуацију како је у примеру (41), у којем је апсенс истовремено и (условно речено) агенс формализован апстрактном именицом, као и када се ради о конкретној ${ }^{18}$ (пример 42), односно уколи-

${ }^{14} \mathrm{O}$ овој концепцији, типовима и манифестацијама в. Балек 2021.

${ }^{15}$ Нпр. Спросила сначала легко, без душевной тревоги: «Утерял сына моем о?»

${ }^{16}$ На основу датог значења овај глагол „улази” у парадигму мотивног терять.

17 Уп. модел терять - потерять - Ø (*потеривать). Код утеривать, насупрот другом члану у низу, у својству апсенса појављује се лична заменица за 1. лице једнине у акузативу (живо /+/): Не утеривайте меня... Николай Аполлонович.

${ }_{18}^{18}$ Ни утерять ни потерять немају допуну у виду градивне именице, нпр. вино, са 
ко се врши градација каритивности (43): (41) B тех вариантах терялась [потерялась; утерялась] только жизнь, в этом - и жизнь и честь; (42) Потолок, стены огромного дансинга терялись [утерялись, потерялись] где-то в синеватой мале; (43) Между тем на практике все сроки были сразу разрушены и необходимая связь между операциями отдельных фронтов быстро утеривалась [утерялась, потерялась]. Семантичка неподударност код теряться, nотеряться и утеряться - утериваться присутна је једино у последњем значењу, где се каритивна семантика транспонује у афективну сферу - 'лишити се спокоја, хладнокрвности, трезвености':19 (44) Однако, согласно даннылм исследований, проведённых на Западе, подавляющее большинство мужчин теряются [потерялись; *утерялись] при виде женщины в ярком наряде.

2.9. Репрезенти каритивног значења могу бити и негирани облици глагола хватать (искључиво у 5. значењу према МАС) односно хватить (у 10-ом), међу којима се видска кореспонденција успоставља управо у датом домену. Будући да је реч о негацији, апсенс се граматикализује генитивном објекатском допуном, док је оријентир-агенс представљен дативом или пак такође генитивом (у оквиру посесивне конструкције $y+$ ген.). Појмови на позицији апсенса могу бити и конкретни и апстрактни, док оријентири могу представљати како метафоричке ентитете у својству законодавних тела тако и појединачна лица и сл.: (45) А исполнительной власти не хватает жёсткости, присущей Трошеву; (46) Но сил для этого у старого человека не хватило, он сорвался, упал и скончался от полученных травм.

2.10. Са аспекта информационе структуре и перспективизације ситуације и глаголи из семантички супротстављене скупине, какви су получать и получить, могу се уврстити у каритивне репрезенте уколико објекатска допуна означава конкретне, измерљиве појмове, а оријентир-посесор је контекстуално експлициран - обично је то ентитет с обележјима живо /+/ и људско /+/, нпр.: (47) [...] и если учитель не врал, то за Ози он получил чуть больше чем три тысячи. Дакле, учитель (рус. учитель) - оријентир-посесор - примио је три хиљьаде (рус. три тыссячи), што представља објекат. Са аспекта перспективизације денотиране ситуације лако се да̂ закључити да је особа која је дала новац - агенс ${ }^{20}$, три хиљаде - апсенс ${ }^{21}$, а особа која их је узела - оријентир. Уп.: (47a) X отдал Y за Ози больше чем три тысячи; (47б) Я лишился трёх тысяч за Ози. Поред тога, информациона структура мора имплицирати да је оријентир ${ }^{22}$ поседовао одређени ентитет, да није посредник. Стога уколико изостане неки од горенаведених услова, није реч о каритивној ситуацији. То је случај у следећим примерима, иако се у (48б) агенс граматикализује генитивном конструкцијом с пред-

способношћу да промени своје квалитативне особине. Уп. постепени губитак својстава карактеристичних за дату лексему, а не њено физичко одсуство (што би био случај уколико би се наведени глагол НСВ заменио поменутим варијантама СВ): Чтобы вино даром не терялось, я поднёс чайник ко рту и вытянул из носика хороший ледяной глоток.

19 У НКРЯ се у датом значењу не јављају утеряться - утериваться.

${ }^{20}$ Премда није контекстуално експлициран.

${ }^{21}$ Давалац новца се свесно лишава наведене суме.

22 У дубинској структури, заправо, агенс јер он даје одређени ентитет. 
логом от: (48а) Вика получила красивое платье; (48б) Вика получила красивое платье от Саши (примери наши). Међутим, пошто се каритивност одликује ниским степеном граматикализације, а, уз то, у словенским језицима је готово у потпуности неистражена, пружа разне интерпретативне могућности. Сматрамо да одређена лексичка средства могу указивати на модификацију ситуације, прелазак из не-каритивне у каритивну, чак и уколико немају дато значење, захваљујући управо информационој структури. Уп. придеве новый и свежий 23 који у (49), због пресупозиције, указују на каритивност, док, с друге стране, у (50) прва наведена лексема не упућује на дато значење: (49) Здание получило новый / свежий взгляд [ヶ лишилось старого взгляда] (пример наш) vs. (50) Hau город получил новую гидроэлектростанцию [Ғ лишился (старой, первой и т.п.) гидроэлектростанции] (пример наш).

3. Спроведена анализа је показала да се каритивно значење посматраних глагола манифестује кроз опште одсуство посесије - лишить/лишать, (не) хватить/хватать, отсутствовать и др.; насилно отуђивање/недозвољено присвајање - отобрать(ся)/отбирать(ся), отнять (ся)/отнимать (ся); и (метафоричко) кретање - удалять (ся)/удалить (ся), отчуждать(ся)/отчудить (ся) ${ }^{24}$; а да граматикализација и семантичке улоге партиципаната зависе од њиховог броја у каритивној ситуацији. Наиме, апсенс се уз посматране глаголе из семантичке сфере отуђивања/лишавања реализује махом на позицији семантичког објекта (најчешће у акузативу и генитиву), осим уз рефлексивне облике када може бити семантички субјекат. Иако су оријентири често агенси, постоје одступања у оним случајевима када се у контексту појављују други партиципанти - нпр. (пасивни) посесор је оријентир (именица у номинативу, генитиву или дативу, те формализована помоћу конструкција om/y + ген.) уколико је експлициран агенс који контролише ситуацију и утиче на одсуство/неукључење апсенса. Захваљујући информационој структури и перспективизацији глаголе получать/получить уврстили смо у глаголске репрезенте каритивности, али и придеве новый и свежий када су атрибути именица у улози апсенса уз наведене глаголе. С обзиром на низак степен граматикализованости каритивне семантике, наредне етапе истраживања требало би да садрже контролу као значајан фактор приликом дефинисања улога партиципаната.

\section{Цитирана литература}

Архипов, Александр В. Типология комитативных конструкций. Москва: Знак, 2009.

[Arkhipov, Aleksandr V. Tipologiiâ komitativnykh konstruktşı̆. Moskva: Znak, 2009.]

Balek, Tijana. «Propriétés aspectuelles des verbes russes désignant l'action de‘ «acquérir» et leurs équivalents serbes» [Аспектуальные особенности глаголов с общим значением ‘приобрести’ в русском языке и их сербские эквиваленты]. [In:] T.

${ }^{23}$ У литератури посвећеној каритивима у руском језику издвојени су нпр. придеви сухой, пресный и пустой (Толстая 2008), а у домаћој празан (Миланов 2019).

${ }^{24}$ Могуће су транспозиције у апстрактне сфере (нпр. у емоционалну). 
Milliaressi (éd.) La relation temps/aspect: approches typologique et contrastive. Lille: Université Charles-de-Gaulle - Lille 3, 2018, 341-348.

Балек, Тијана. Дефектност видске парадигме у руском и српском језику [необјављена докторска дисертација]. Нови Сад, 2021.

[Balek, Tijana. Defektnost vidske paradigme u ruskom i srpskom jeziku [neobjavljena doktorska disertacija]. Novi Sad, 2021.]

Боханова, Айгуль С. «Вербализация категории лишительности: критерии ограничения». Вестник КазНУ. Серия филологическая 1-2, 2013: 169-173.

[Bokhanova, Aı̆gul' S. «Verbalizatșiiâ kategorii lishitel'nosti: kriterii ogranicheniiā». Vestnik KazNU. Seriiâ filologicheskaiā 1-2, 2013: 169-173.]

Lehmann, Christian. „Predicate classes and participation“. [In:] H. Seiler, W. Premper (eds.) Partizipation: Das sprachliche Erfassen von Sachverhalten (Language universals series 6). Tübingen: G. Narr, 1991, 183-239.

Lehmann, Christian. „Participant roles, thematic roles and syntactic relations“. [In:] T. Tsunoda, T. Kageyama (eds.) Voice and grammatical relations. Festschrift for Masayoshi Shibatani (Typological Studies in Language 65). Amsterdam - Philadelphia: John Benjamins, 2006, 153-174.

Иванов, Вячеслав В. «Типология лишительности (каритивности)». [В:] В. В. Иванов, Т. Н. Молошная (ред.) Этюды по типологии грамматических категорий в славянских языках. Москва: Изд-во Индрик, 1995, 5-59.

[Ivanov, Viācheslav V. «Tipologiiâ lishitel'nosti (karitivnosti)». [V:] V. V. Ivanov, T. N. Moloshnaiâ (red.) Ėtiưdy po tipologii grammaticheskikh kategoriǔ v slaviânskikh iâzykakh. Moskva: Izd-vo Indrik, 1995, 5-59.]

Миланов, Наташа М. „Прилог опису семантике придева празан”. Наш језик L/2, 2019: 449-456.

[Milanov, Nataša M. „Prilog opisu semantike prideva prazan”. Naš jezik L/2, 2019: 449-456.]

Оскольская, Софья А., Наталья М. Заика, Сергей Б. Клименко, Максим Л. Федотов. «Определение каритива как сравнительного понятия». Вопросы языкознания 3, 2020: 7-25.

[Oskol'skaiā, Sof'iā A., Natal'iā M. Zaika, Sergeř B. Klimenko, Maksim L. Fedotov. «Opredelenie karitiva kak sravnitel'nogo poniâtiiā». Voprosy iâzykoznaniiâ 3, 2020: 7-25.]

Радчук, Ольга В. «Корреляция понятия «отсутствие» с семантическими категориями лишительности, каритивности и необладания». Русская филология. Вестник Харьковского национального педагогического университета имени Г. С. Сковороды 4(70), 2019: 52-57.

[Radchuk, Ol'ga V. «Korreliâtsiiâponiatiiā «otsutstvie»s semanticheskimi kategoriaami lishitel'nosti, karitivnosti i neobladaniiā». Russkaiā filologiiā. Vestnik Xar'kovskogo natsional'nogo pedagogicheskogo universiteta imeni G. S. Skovorody 4(70), 2019: 5257.]

Толстая, Светлана М. Пространство слова. Лексическая семантика в общеславянской перспективе. Москва: Изд-во Индрик, 2008.

[Tolstaiā, Svetlana M. Prostranstvo slova. Leksicheskaiā semantika v obshcheslaviānskoĭ perspektive. Moskva: Izd-vo Indrik, 2008.] 


\section{Извори}

БАС: Словарь современного русского языка (ред. В. И. Чернышов). Т. 1-17. Москва - Ленинград: Изд-во АН СССР, 1950-1965.

[BAS: Slovar' sovremennogo russkogo iāzyka (red. V. I. Chernyshov). T. 1-17. Moskva - Leningrad: Izd-vo AN SSSR, 1950-1965.]

MAC: Словарь русского языка: В 4-х томах (ред. А. П. Евгеньева). <http://febweb.ru/feb/mas/mas-abc/default.asp> 07.04.2021.

[MAS: Slovar' russkogo iazyka: V 4-kh tomakh (red. A. P. Evgen'eva). <http://febweb.ru/feb/mas/mas-abc/default.asp > 07.04.2021]

НКРЯ: Национальный корпус русского языка. <https://ruscorpora.ru/new/> 17.04.2021.

[NKRIâ: Natșional'nyı̌ korpus russkogo iāzyka. <https://ruscorpora.ru/new/> 17.04.2021]

ТСРГ: Толковый словарь русских глаголов. Идеографическое описание (ред. Л. Г. Бабенко). Москва: АСТ-ПРЕСС, 1999.

[TSRG: Tolkovyı̌ slovar' russkikh glagolov. Ideograficheskoe opisanie (red. L. G. Babenko). Moskva: AST-PRESS, 1999.]

Тияна Балек

\section{О ЛЕКСИЧЕСКОЙ КАРИТИВНОСТИ, РЕПРЕЗЕНТИРОВАННОЙ ГЛАГОЛАМИ, И ГРАММАТИКАЛИЗАЦИИ ПАРТИЦИПАНТОВ В РУССКОМ ЯЗЫКЕ}

\section{Резюме}

В данной статье анализируются (1) представление каритивности (лишительности) на лексическом уровне с помощью глаголов, принадлежащих к семантическому классу отчуждения, напр. лишать (ся) - лишить(ся), отчуждать, не хватать - не хватить и др., и (2) грамматическая формализация партиципантов. Благодаря перспективизации и информационной структуре высказывания в качестве каритивных показателей были рассмотрены глаголы получать - получить, а также прилагательные новый и свежий. Анализ показал, что у рассматриваемых глаголов каритивность осуществляется как отсутствие посессии, (метафорическое) движение, принудительное отчуждение и присвоение без разрешения. Семантическая и синтаксическая роли партиципантов зависят от их числа и валентностного потенциала конкретного глагола. Обязательный участник каритивной ситуации - абсенс (недостающий элемент, занимающий позицию субъекта или объекта), а роли ориентира и агенса могут альтернировать, кроме в тех случаях, когда в ситуации эксплицируется пассивный обладатель.

Ключевые слова: каритивность, глаголы, абсенс, ориентир, партиципанты, агенс, субъект, отчуждение. 